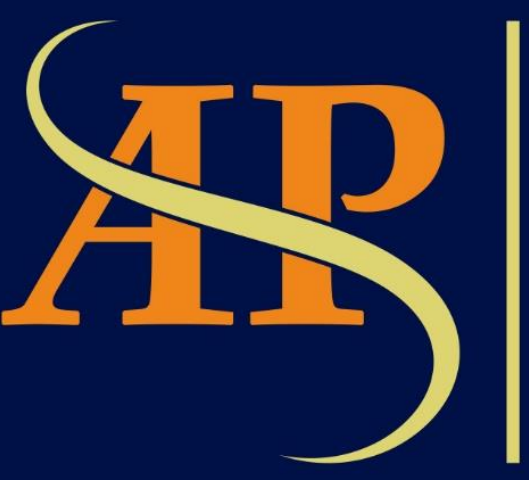

JURNAL

ASIA

PACIFIC

STUDIES

Journal of International Relations Study Program Faculty of Social and Political Sciences

Universitas Kristen Indonesia

Volume I | Number 2 | July - December 2017 


\title{
THE ROLE OF MULTINATIONAL CORPORATIONS IN COUNTERING TERRORISM: THE CASE OF TELEGRAM IN INDONESIA
}

\author{
${ }^{1}$ Fahri S. Altakwa, ${ }^{2}$ Risnanda P. Irawan, ${ }^{3}$ Victoria M. Pakpahan \\ ${ }^{1,2,3}$ International Relations, Faculty of Humanity, President University, Jababeka Education Park, Jl. Ki Hajar \\ Dewantara Kota Jababeka, Bekasi, 17550, Indonesia \\ lfahrisurya296@gmail.com, ${ }^{2}$ risnandapradityairawan@gmail.com, ${ }^{3}$ victoriampakpahan@gmail.com
}

\begin{abstract}
In this globalization era, there are new emerging actors especially in international trade which is the multinational corporations (MNCs). On the other side, there is terrorism which has evolved throughout history. It is perceived that globalization and international trade can be a factor of terrorist establishment, while massive destructions by terrorism is crucial as a factor for the international business and multinational corporations to operate. One of the product by multinational corporations is in social media sector, and nowadays, terrorist also can use the social media to recruit their member which challenging multinational corporations. In explaining this phenomenon, this paper will use the case study of Telegram in Indonesia. This paper will cover the correlations between terrorism and MNCs, the particular case study of Telegram, and addressing the role of MNCs in countering terrorism through qualitative data gathered from various books, journals, and news. In conclusion, the MNCs should play role as a proactive approach in the long term to counter terrorism through cooperation with government and its own strategic commitment in contributing to a secure society.
\end{abstract}

Keywords: Multinational Corporations; Terrorism; Social Media;

\begin{abstract}
Pada era globalisasi, hadir aktor-aktor baru dalam perdagangan internasional, atau yang kita kenal sebagai perusahaan multinasional. Di sisi lain, terorisme terus berkembang seiring zaman. Berhubungan dengan hal ini, terdapat gagasan bahwa globalisasi dan perdagangan internasional dapat menjadi faktor dalam kemunculan kelompok-kelompok teroris, sebaliknya kerusakan dan dampak yang ditimbulkan oleh kegiatan terorisme juga merupakan faktor yang penting bagi bisnis internasional dan perusahaan multinasional dalam menjalankan kegiatan operasionalnya. Salah satu produk dari perusahaan multinasional adalah sektor media sosial, dan dalam perkembangannya, teroris juga dapat menggunakan media sosial untuk merekrut anggota dan menjalankan kegiatan mereka, di mana hal ini menimbulkan tantangan baru bagi perusahaan multinasional tersebut. Dalam menjelaskan fenomena ini, makalah ini akan menggunakan kasus Telegram di Indonesia sebagai studi kasus. Di dalamnya akan mencakup korelasi antara terorisme dan perusahaan multinasional, pembahasan spesifik mengenai kasus Telegram, dan bagaimana perusahaan multinasional dapat mengambil peran dalam mengatasi masalah terorisme. Pembahasan makalah ini akan menggunakan metode kualitatif melalui data yang dikumpulkan dari buku, jurnal, dan berita. Sebagai kesimpulan, perusahaan multinasional diharapkan untuk dapat berperan proaktif terutama dalam pemberantasan terorisme dalam jangka panjang melalui kerja-sama dengan pemerintah dan melalui implementasi komitmen perusahaan dalam membangun masyarakat dan lingkungan yang aman.
\end{abstract}

Keywords: Perusahaan Multinasional; Terorisme; Media Sosial; 


\section{Introduction}

Earlier this year, Indonesian government blocked one of social media platform which is called as Telegram. The reasons behinds this action is Telegram have been used as a tool by terrorists to share propaganda, secret communication and recruitments for the new members. In recent development, both government and Telegram's representatives meet up and discuss about this issue then cooperate to tackle the problem of terrorism. On this journal article, we emphasize the Telegram as an example of social media MNCs and examine its role on managing terrorism issue. This topic is crucial because MNCs particularly social media company have been used as the media to easily launch terrorism operation, hence their involvement as an active actor is important to address the issue in the long run.

This article consists of background in which the reasons of this topic of the relations between MNCs and terrorism is chosen with a special case study of terrorism activities in Indonesia. Next, it will examine further how terrorism and MNCs can correlate, also responding on the emerging role of MNCs and how they can contribute which we take as our research question. Third, providing theoretical framework of liberalism which highlight cooperation between several actors, elaboration of terrorism ideas and social media MNCs concept. Next is the case study of the event between Indonesian government and Telegram company and the discussion of its implication to the connection of MNCs and terrorism in general.

Finally, the result of discussions will instigate the thinking over responding the issue of terrorism in which cooperation between government, MNCs and society is needed whether in the form of reactive or proactive approach whereas this article suggests the latter as a method that we should develop for the long term. Particularly for the MNCs, strategic commitment on ethical conduct, guidance like General Business Principles, policy on human rights, and responsibility towards society that can be practically implemented are significant keys in contributing on counter-terrorism other than compact system in their business and program in collaboration with the government.

\subsection{Background}

Terrorism nowadays has become one of the great concerns of the international society. It spreads fear to the people, disrupting political and economic activities, on the other hand it successfully snatched the people attention, direct government attention towards them, and founding new recruits to support their organization. Terrorism has its violent roots in the past time, conducted by either states or non-state actors. However, with the current development of globalization, it seems that terrorism also manage to make use of them.

On the other hand, the other product of globalization is the multinational corporations (MNCs). As the world become interdependence especially in terms of trade and economic globalization, MNCs emerge as an important actor. In the surface, it seems like there is no correlations between the two actors, yet in further research, both actors will reciprocally affect each other, since the increasing international trade and economic globalization failure is argued as one of the reason of the emerging groups of terrorists and conversely, the act of terrorism will affect the business conduct, not only when it is physically happened, but also in terms of assessment in doing business and trade relations with particular country or in particular region.

There are several cases in which we can see the effects of terrorism to MNCs, for examples are the 11 September 2001 occurrence in the United States, or the 2016 Sarinah bombing attack in Indonesia. To analyze deeper the relations between MNCs and terrorism, further explained is the case of Telegram (as an MNC) banning in Indonesia because of 
terrorism use within it and the presumption of no regulations or actions conducted by Telegram in addressing the case. Furthermore, Telegram engaged in social media sectors while the role of media and information exchange is very significant on countering terrorism in this globalized world.

\subsection{Formulation of the problem}

Based on background, we would like to propose the role and ways of multinational corporations specifically social media company contribution in terrorism and the efforts on countering terrorism through proactive approaches.

\subsection{Purpose and objectives}

On this jurnal we would like to identify the correlation between terrorism and multinational corporations and assess the role of multinational corporations in managing terrorism as a proactive approach in the long run.

\subsection{The Purpose of Research}

The finding of this paper will be beneficial for the public and academic community considering the contemporary era of globalization in which terrorism and multinational corporations are two emerging actors that are very important. In this interconnected world, terrorism can occur anywhere and anytime, while the multinational corporations have the significance in trade and economic relations between people outside the border. The information contained in this paper will give new perspectives of how to utilize multinational corporations in countering terrorism.

\section{Literature Review}

To further understand the issue of terrorism and the emerging MNCs actor, theory and concepts are needed as the foundation. We use the idea of liberalism as a fundamental theory to break down the role of a non-state actor on terrorism oppression, further explanation on the concept of terrorist, lastly is terrorist actor and the web-based social networking MNC's connection to terrorism action.

\subsection{Liberalism}

Waltz (1959) infers that liberalism contends that state is not the only actors, the inner social groups, the relation between civil society and state will construct of the states in the worldwide relations, and the circumstance of the state (Schneider 1960), which additionally impacting the government approach to the role the state or the conditions on international relations. Furthermore, it will influence the method of the state to respond to the particular issue, for instance, psychological warfare.

As a piece of liberalism, there is additionally a hypothesis called liberal institutionalism. Liberal institutionalism contends that the significance of international government and universal associations in global relations. By common notion objectives in the worldwide framework and the collaboration of states (Devvit 2011). International organization believes that there will be the collaboration in handling some issues which experience by nations in the world followed by the common thought.

Besides, liberal institutionalism additionally discussed the effect of non-state actors in world issues, for example, transnational associations and non-governmental organization 
(Devvit 2011). Particularly in this globalization time, MNCs has the critical part in the technology advances and communications which help the globalization. In particular, MNCs assume part on the stream of data which don't perceive the power and doesn't take quite a while. For instance, Facebook, Instagram, Twitter, and Telegram.

\subsection{Terrorism}

There are some definition about terrorism. One of definition was made by Yohan Alexander (1976) to express that utilization of viciousness against nonmilitary personnel focuses to scare or to make huge dread to achieve objectives (Yonah 1976). Terrorism is the universal issue which faced by states in the world. That since they utilize a weapon to risk the general population and utilizing regular people as an objective and pulverization of infrastructure, hazardous alarm for society and the broke of financial activity. The significance is terrorist will hurt the unsecured civilians which do not connect with the terrorism but rather turned into the casualties.

There is a lot of terrorist assaults happened. 9/11 in 2001 assault in the United States, Bali Bombing in 2005, or London Bombings in 2007. Those are the course of events on terrorism assault which occurred in three regions, and numerous more assault we have not mentioned which giving mass pulverization and hundred individuals died.

Tackling terrorism issue universally began in February 2005 as the main meeting of counterterrorism in Saudi Arabia. At that point, on September 8, 2006, the United Nations General Assembly (UNGA) received a direction Plan of Action comprises of four pillars, such as: measure to address the conditions conducive to the spread of terrorism, prevent and combat terrorism, manufacture states ability to prevent and battle psychological oppression and to fortify the part of UN framework on terrorism, guarantee the respect of human rights for all and the rule of law as the fundamental basis for the battle against terrorism which actualized domestically in each state (United Nations 2017).

\subsection{Social Media MNCs and Terrorism}

As we realize that in time of globalization, which the stream of information implies the easiest way to contact with individuals without meeting, social media can be a way to accomplish terrorism purpose by sharing our information, getting a companion, upload video, sharing note, and so forth. Along these lines could be the way the terrorist attack could assault the civilians. Along these lines additionally took after by ISIL (The Islamic State of Iraq and the Levant) which is the big terrorist association worked in Syria, Libya, and Iraq.

The common denominator factor is the reason that everybody who is radicalized and enlisted online feels sympathetic toward that group, and individuals who feel there is "something missing" from their lives seem, by all accounts, to be more helpless than others (Alarid 2006, 314). Expanding empathy feeling of the general population feeling despises, purposeful publicity which shared through online networking either by sharing status or video of killing to pick up consideration then after that regular citizen either youthful or old need to include to be the new part.

To reach to be more successful, terrorist utilizing numerous strategies to convey on the web. For example:

a. Terrorists can draft an email message and spare it as a draft instead of sending it so anybody with access to that email record can sign in and read the message. Known as "dead drops," these interchanges are less subject to interception (Alarid 2006, 320). Terrorists can post training booklets on the web or even hack into a true blue-site and shroud preparing materials "somewhere down in apparently harmless subdirectories of 
the true blue-website," a procedure known as "parasiting" (Alarid 2006, 320). Terrorists can lead look into on potential targets on the web, where both text and imagery, including satellite photography, is as often as possible accessible. Google Earth, for example, has been utilized to target British troopers in Iraq with expanding exactness (Alarid 2006, 320).

b. Terrorists can appear anonymously for asking donations of financial or other support via website to support their actions (Alarid 2006, 321).

Those are the part of social media MNC on terrorism, this is the way MNC parts particularly web-based social networking as their devices to select more individuals which provided by media. Terrorist particularly the huge association like ISIS and ISIL which fundamentally following the change of innovation and utilizing web-based social networking MNC resembles Facebook, Twitter, WhatsApp to enrolled and offer propaganda to civilians to get their emphatic to follow the groups' either youthful or old individuals.

\section{Results and Discussion}

\subsection{Globalization, Terrorism and Multinational Corporations}

Terrorism activities are not a new occurrence in contemporary globalization era. Throughout history, there have been major incidents as though the use of violence with public exposure to make people or nations to submit in Roman Empire, during French Revolution time, or the more modern example in Nazi Germany, China in Mao period, and other totalitarian regimes. The examples mentioned before can be considered as states or government's conduct. Similarly, even in the past, non-state actors also commit this act of violence and coercion through the spread of fear. The examples are assassins killed in crusades period, the assassination of Franz Ferdinand that triggered the World War I, and the infamous 11 September 2001 with the rise of terrorism organization under the banner of religion (Männik 2009). Some cases might seem to be not terrorism conduct as what people know now, however the key idea is the act of spreading fear with violence and coercion to make the adversaries to comply in certain behavior, to not do some acts, or achieving their interests ranging from political, ideological, or by religious intent. This simplistic way of defining terrorism is based on the definition specified in UN Security Council Resolution 1566 of 2004, US Department of Defense and the European Union definition.

While it is not a new occurrence, the current state of increasing globalization might encourage the spread of terrorism. Many arguments stated that globalization has caused gap between rich and poor, environmental problems, interdependence, domestic and international violence in the negative side of increasing international cooperation of trade, culture, and communications. Under the globalization, MNCs rise as a new actor along with international organizations and civil society movement. The relations between terrorism and MNCs happened here. It is mentioned that terrorism act is in order for the perpetrator to gain their various interests. The argument is that the late terrorist attacks in globalization era is a form of hatred towards capitalism, globalization, and a result of envy because of globalization negative impacts mentioned previously: poverty in some parts, religion, and ill nurtured soil (environment aspect)(Schreiber 1978). Thus, there is a close relation between the MNCs as the actor of the current market structure and economic development with terrorism in which it is argued as an extreme form of expression especially with violence ideology by groups of people towards the current world condition and failure of globalization.

Of course, even though it is viewed as a form of expression, it is still a criminal act in which people and government has tried to fight from time to time. In countering terrorism, there are two ways that people can take: soft way or hard action. Until now, the hard way or 
responding terrorism is very evident, ranging from the involvement of military force, the establishment of either domestic or international bodies to combat and capture terrorists, and cutting their support of weaponry and other resources. Männik (2009) argued that the hard response as mentioned is just effective in the short run or as a response of current attack happened, while in the long run the soft way is needed since we acknowledge that fighting against terrorism is not only physical, but also ideological. The spread of those extreme ideas is the one that we need to prevent and eradicate, even though until now it seems to be an ideal that is impossible to be implemented fully. The soft way or conciliatory response will need a very long time since we need to go to the root cause of terrorism. If it is mentioned that the root cause is because of the failure of globalization, including inequality of economic condition, then a reform of the current situation is needed (Frey 2017). This is why it seems to be unlikely to happen because a good reform and development in the international and market structure is hard to achieve.

It is not that the government and international society do not know about this soft way of addressing the root cause of terrorism. According to Schreiber, it is just often mentioned and discuss but without clear practical framework and implementation because it will include comprehensive diplomatic agendas, long-term economic growth plans, social and cultural adjustments of parts of the world. Other than that, logically, when states or MNCs want to do trade or investment, there will be assessment of risks. It is unlikely for them to want to engage with parts of the world in which there are problems of security like terrorism and internal conflict of the government and the opponent groups. Despite this pessimistic view, in addressing the root cause of terrorism and failure of globalization, in summary here are the things that international communities should do in the long run: (1) considering the type of trade that would be beneficial for countries in which many terrorists groups developed and specially to have direct effect on its local or people's economy, (2) Improving job opportunities, education and job training that goes with the local culture by international aid agencies for the local's steady growth, (3) foreign Direct Investment (FDI) in local projects, joint ventures, and multilateral financial support for infrastructure development, (4) efforts to implement the rule of law. The acknowledgement that the use of force to counter terrorism also raise economic concerns, serious civil and human rights issues (Fandl 2003).

Now, to be more specific on terrorism and multinational corporations link. Pictured above is how the international trade can be the reason of terrorist group establishment and for the people that share the common ideas to join them. On the other way around, terrorism will also affect MNCs. The big example is the event of September 11. Therefore, the MNCs will need risk management, careful recruitment, expatriation, insurance, security, and operational hindrance especially because they operate in different region with the system of home and host states(Putrawenas 2004), hence it shows the concern from MNCs towards terrorism. As MNCs is a major actor of globalization and international trade, we believe that they need to also take role in countering terrorism, either through cooperation with government and communities, and by considering the long term soft ways mentioned above. The MNCs need to not only seek for capital profit, but also social and environmental aspects. Putrawenas (2004) suggested three main proactive approaches that MNCs could do without hard power instruments needed:

Strategic commitment on ethical conduct, means that the MNCs should have guidance like General Business Principles, policy on human rights, and responsibility towards society that can be practically implemented. Reputation management, this is related to communication with the society. The main objective is for them to know the conduct of MNCs in which they 
are responsible and contributing for communities' development. This is also means building image and trust of the society towards the MNCs. Cooperation with other MNCs, the ideas above must be committed by all MNCs as there is a tendency to generalize all MNCs to undertake similar actions, especially if it is damaging the society.

To further see the relations of MNCs and terrorism in which they have reciprocal effects toward each other, this paper uses the case study of Telegram - as the representative of $\mathrm{MNCs}$ - and terrorism in Indonesia. Before proceeding to the case study, it is necessary to know that Telegram operates in social media sector and a short description over the importance of information and media in the emergence of terrorist group or countering it.

MNCs have wide variations of sectors. One of the most popular and known is the social media platform. We have Facebook, Twitter, Instagram, WhatsApp, Line, and as mentioned in this case: Telegram. The social media make information exchange to be easier and faster. All groups of people now engage in it, with various background, age, and wherever they live. The positive side comes with the downside of exchanging 'bad' information and influencing ideas or perceptions of the people. Lack of information and knowledge might make people desperate and easy to manipulate, as does the current situation of the wide spread of information, regardless of it is true or not, or whether it is good to know or not(Kuusik 2010). It is good to know the occurrence from other parts of the world including crisis, conflict, and the existence of terrorism act. However, there are people who then learn, share the same experience or influenced by the extreme ideology, having common interests, and the social media might help them to reach the other. Therefore, there are recruits of major terrorist groups through the social media and an easier way of communication also for them. As the MNCs should promote and engaging in counter terrorism, then in this case, the social media MNCs ideally should have regulation in preventing the spread of violence and to become a media of peace promoting including screening, censorship, legal regulations, cooperation with the government, or even voluntary self-restraint (Frey 2017).

\subsection{Case Study: Terrorism and Telegram Banning in Indonesia}

A few months ago, Indonesia was overwhelmed with its government policy, directly from the communications and informatics ministries over blocking one of the social media sites that are widely known among the masses in the world especially Indonesia. Not to mention the social media is still quite young because of the new establishment in the range of 2013 (Hakim 2014). Before the blocking, Ministry of Communications and Informatics party has been first to coordinate with the Police, the National Agency for Counter-Terrorism, and several other partners and officially on Friday, October 14, 2017, Ministry of Communications and Informatics, announced the blocking of social media access which is telegram in Indonesia (Haryanto 2017). Spontaneous, loyal telegram users disappointed and blame the Ministry of Communications and Informatics who has decided to block Telegram services in Indonesia. Behind the blockade, the government has a good reason to do so, which according to the communications and informatics ministry as the technology, telegram agencies have violated the Electronic Information and Transactions Act because they believe that there are several channels or pages detected containing content of radicalism or terrorism (Biro Humas KemenKomInfo 2017). The content is propaganda over radicalism, terrorism, hatred, invitation or how to assemble bombs, how to attack, disturbing images, and others that are contrary to Indonesian laws and regulations (Islami, KemenKomInfo 2017). A strong reason for the blocking was that it found about 17,000 pages linked to terrorism and other radical acts within Telegram (Sadewo 2017). 
In this technological era, besides the prohibition of terrorism that we face today, the threat of terrorism is increasing (Diandra 2016). Today cyberspace has become a place of recruitment, meet, and dissemination of these teachings. In Indonesia, to overcome the problem of terrorism in particular social media such as telegram as their container to distribute it, the Ministry of Communications and Informatics has sent about six emails to the telegram regarding the request for blocking negative content in Telegram. The decision was taken after considering the lack of goodwill from Telegram, since it was sent the 6th email from Tuesday, July 11, 2017 to Thursday night on July 13, 2017 (Tribun Medan 2017). The government stated that the blocking is an anticipative step towards the development of terrorism movement which is suspected to use the application. In addition, since the occurrence of acts of terror in Indonesia within a period of two years; perpetrators of terror on MH Thamrin street (January 14, 2016), Terror of Kampung Melayu (May 24, 2017), and police stabbing in Falatehan Mosque (25 June 2017), using Telegram app to coordinate and communicate (Andryanto 2017); making the steps taken is not necessarily only for the security of the State.

Although the Ministry of Communications and Informatics has sent an e-mail to the telegram and not one email receives a response, Indonesian government only blocked Telegram services on the website while the application can still be opened via mobile phone. In addition, blocking is also done on 11 domain name system (DNS) Telegram, namely: t.me, telegram.me, telegram.org, core.telegram.org, desktop.telegram.org, macos.telegram.org, web.telegram.org, venus.web.telegram.org, pluto.web.telegram.org, flora.web.telegram.org, flora1.web.telegram.org (Ayuwuragil 2017).

Telegram founder as well as the CEO, Pavel Durov, was initially surprised to learn about the actions taken by the Indonesian government through his twitter account. However, after he clarified the issue, he admitted that he had ignored the blocking request email from the Ministry of Communications and Informatics. The CEO of the telegram argued that there had been miscommunication all along, and admitted that the Ministry of Communications and Information had indeed contacted them, but was not responded by the Telegram team. He also deplored the request of the Indonesian government to close the terrorism channel in Telegram and they did not quickly process it.

Durov in a meeting at TechCrunch Disrupt in 2015 and claimed the existence of terrorist activities of ISIS groups who use the application (Engel 2015). With the evidence above, it is clear that the Telegram's CEO has actually put his attention to the eradication of terrorism; however, email miscommunication email from Indonesia caused the problem to be more soluble a few months ago. Telegram is an application that chooses the path of "open sources" and is different than its competitors. Its use can be for positive to negative purposes. Plus, Telegram Messenger is a messaging service with a high level of security. In Telegram services, they offer at least two types of chat. First is the regular chatting and the second is a special chat called "secret chat"(Zaenudin 2017). Secret chat is a high-security messaging feature like endto-end encryption, promising no traces left, self-destructive features, to not allow forward action on the message which is when person A screen-captures the conversation, the notification that person $\mathrm{A}$ has been doing will be sent to person B. In addition to chat, Telegram also has other services such as "channels" which is a feature of broadcast messages. Every fellow user's conversation is encrypted and cannot be hacked. Telegram is a favorite for international terrorist networks. This conversation app is able to accommodate 10 thousand members, then, send messages faster than any similar application, and can send photos, videos, and documents of various types, ranging from doc, zip, mp3, and so forth, up to 1.5 GB capacity (Tribun Medan 2017). It is mean that Telegram has very difficult to detect. This is a big problem. According to Durov, the terrorist group is safe talking about brutal attacks through Telegram because it 
cannot be tapped and tracked (Aditya 2017). But with the user's privacy reasons, Durov continues to develop Telegram.

\subsection{Multinational Corporations in Countering Terrorism}

In response to the telegram's CEO at the request of the Indonesian government, Pavel Durov is ready to cooperate by offering several counter-terrorism schemes with the Government of Indonesia. Durov has followed up on the requested by the Ministry of Communications and Informatics and proposed a special communication for the process of handling negative content especially radicalism or terrorism under the guidance of Ministry of Communications and Informatics will follow up as soon as possible from the technical side of the details so that the Standard Operating Procedure (SOP) can be implemented immediately for the misunderstandings that have occurred, Durov offers three steps.

It has and will soon block all terrorist-related public channels according to the Ministry of Communications and Informatics report. Telegram will establish direct communication with the Government of Indonesia through the Ministry of Communications and Informatics so that future will be more efficient in identifying and blocking terrorist propaganda. Telegram will form a moderator team that truly understands Indonesian language and culture in order to process reports related to terrorist content more quickly and accurately (Tribun Medan 2017).

Upon receipt of a communication from the Telegram to the Ministry of Communications and Informatics, the next follow-up is a technical SOP preparation such as process, human resources, organization, etc. as follows: (1) the possibilities of making Government Channel communicate with the Ministry of Communication and Information Technology more quickly and efficiently, (2) The Ministry of Communications and Informatics will request to be granted authority as Trusted Flagger against accounts or channels in Telegram services, (3) The Ministry of Communications and Information Technology will ask Telegram to open a representative in Indonesia.

For the process of content filtering governance, the Ministry of Communications and Information continues to improve both process, organizing, technical, and human resources (Biro Humas KemenKomInfo 2017).

Indonesia in response to the problem, trying to find ways to maintain the security of the country and in Cyber security case as a threat that cannot be underestimated especially if its negative contents scattered on the internet. Indonesia will adopt a "whitelist" (Islami 2017). The whitelist is the opposite of a blacklist. In a nutshell, the way it works is registered domain can be automatically accessed while unregistered means cannot be visited the site.

In a wider perspective, indeed, even there is no international principle which bound MNC's in worldwide the states ought to be capable to put the techniques on handling terrorism domestically which includes all actors inside. The US as the first state assaulted by terrorism on $9 / 11$ oppression. At that point, they put the part of MNCs on handling fear terrorism as an obligation (Kokaz-Muslu 2006).

The example is between Commerce Guard. This participation between General Electric and Siemens by prepare equip containers utilized as oceanic transportation for checked the ship give GPS device would detect the cargoes amid travel. Likewise give quicker moving cargo, better business benefits for both organization and secure the states. This collaboration amongst MNCs and state result win-win circumstance (Kokaz-Muslu 2006, 46-47).

This is the example of state implemented preventive activity to handling psychological oppression by securing the flow of coordination and freight over the territory which the US officially actualized identified with the collaboration amongst MNCs and United States. Indeed, even MNC likewise have benefits of interest towards this activity. Be that as it may, these 
MNC's role on terrorism is giving the innovation as an apparatus to avert terrorism which can provide by qualified MNCs. This is one of activity react to terrorism which diverse nations have their own particular strategy to handling this issue.

\section{Conclusions and Recommendations}

In the conclusion we would like to re-state that states and MNCs should cooperate in purpose to tackling terrorism. Especially in the contemporary era when technology support the flow of information becomes easier and faster. Essentially, terrorism existed since ancient era while the emerging terrorism in recent years is resulted by globalization and international trade. On the other side, maximizing the role of actors is crucial including the role of MNCs. In the case of Telegram in Indonesia there are three principles should be conduct between Indonesia government and Telegram company. First is Telegram should block all terrorist-related public channel based on Ministry of Communications and Informatics report. Second, established direct communication with Indonesia through Ministry of Communications and Informatics efficiently to identify and blocking terrorist propaganda. Last, Telegram form moderator team which fully understand Indonesia language and culture, in order to process report related to terrorist quickly and accurately. While in the wider perspective, MNCs as well as the international society should reform the current international structure regarding economic and trade, cooperate with other actors as well as other MNCs, and to build trust among society. 


\section{REFERENCES}

\section{Books}

Alarid, Maeghin. 2006. "Recruitement and Radicalization: The Role of Social Media and New Technology." In Impunity : Countering Illicit in war and transition, by Michael Hughes and Michael MIklaucic. United States: Center for Complex Cooperation.

Schreiber, J. 1978. Ultimate Weapon - Terrorists and World Order. New York: William Morrow and Co, Inc.

Yonah, Alexander. 1976. International Terrorism : National, Regional, and Global Perspective. New York: Praeger.

\section{Journals}

Fandl, Kevin J. 2003. "Terrorism, Development \& Trade: Winning the War on Terror Without the War." American University International Law Review Volume 19 Issue 3 587-631.

Frey, Bruno S. 2017. "Countering Terrorism: Deterrence vs More Effective Alternatives." De Gruyter Open Economics 30-35.

Kokaz-Muslu, Jocelyne. 2006. Preventing International Terrorism: Can Multinational Corporations Offer a Fresh New Perspective? Working Paper 1016, bepress Legal Series: bepress Legal Series.

Männik, Erik. 2009. "Terrorism: Its Past, Present and Future Prospects." In Religion and Politics in Multicultural Europe. Perspectives and Challenges, by Andres Saumets and Alar (Ed.) Kilp, 151-171. Tartu: Tartu University Press.

Schneider, Francis J. 1960. "Man the state and War, by Kenneth N. Waltz." Indiana Law Jurnal.

\section{Websites}

Aditya, Reza. 2017. Diblokir di Indonesia, Ini Tanggapan CEO Telegram. July 15. Accessed October 29, 2017.

Andryanto, Dian. 2017. 3 Serangan Teror Ini Diperintahkan Bachrun Naim Lewat Telegram. July 17. Accessed October 29, 2017. https://nasional.tempo.co/read/891949/3serangan-teror-ini-diperintahkan-bachrun-naim-lewat-telegram.

Ayuwuragil, Kustin. 2017. Daftar 11 Domain Telegram yang Diblokir Kominfo. July 14. $\begin{array}{lll}\text { Accessed } & \text { October } 29, & \end{array}$ https://www.cnnindonesia.com/teknologi/20170714185857-185-228028/daftar-11domain-telegram-yang-diblokir-kominfo/.

Biro Humas KemenKomInfo. 2017. Perkembangan Terkini mengenai Pemblokiran Akses Aplikasi Telegram. Press Conference, Jakarta: kominfo.com.

Devvit, Rebeca. 2011. Liberal Institutionalism: An Alternative IR Theory or Just Maintaining the Status Quo? September 1. Accessed October 28, 2017. http://www.eir.info/2011/09/01/liberal-institutionalism-an-alternative-ir-theory-or-justmaintaining-the-status-quo/.

Diandra. 2016. Deteksi Dini dan Respons Cepat untuk Lumpuhkan Terorisme. December 22. Accessed October 2017, 2017. https://www.kominfo.go.id/content/detail/8526/deteksidini-dan-respons-cepat-untuk-lumpuhkan-terorisme/0/sorotan_media. 
Engel, Pamela. 2015. Inside the app that's become ISIS' biggest propaganda machine. November 21. Accessed October 29, 2017. http://www.businessinsider.sg/telegramisis-app-encrypted-propagandar-2015-11/?r=US\&IR=T .

Hakim, Danny. 2014. Once Celebrated in Russia, the Programmer Pavel Durov Chooses Exile. $\begin{array}{lllll}\text { December } 2 . & \text { Accessed } & \text { October }\end{array}$ https://www.nytimes.com/2014/12/03/technology/once-celebrated-in-russiaprogrammer-pavel-durov-chooses-exile.html.

Haryanto, Agus Tri. 2017. Begini Kronologis Lengkap Pemblokiran Telegram. July 18. Accessed October 29, 2017. https://inet.detik.com/law-and-policy/d-3563897/beginikronologis-lengkap-pemblokiran-telegram.

Islami, Nur. 2017. Dampak Telegram dan Ransomware, Indonesia akan Adopsi Whitelist. July 25. Accessed October 29, 2017. https://www.kominfo.go.id/content/detail/10171/dampak-telegram-dan-ransomwareindonesia-akan-adopsi-whitelist/0/sorotan_media.

- 2017. KemenKomInfo. July 31. Accessed Ocotber 29, 2017. https://www.kominfo.go.id/content/detail/10259/hati-teroris-diteguhkan-melaluitelegram-ungkap-kominfo/0/sorotan_media.

Kuusik, Nora. 2010. The Role of the Media in Peace Building, Conflict Management, and Prevention. August 28. Accessed October 28, 2017. http://www.eir.info/2010/08/28/the-role-of-media-in-peace-building-conflict-management-andprevention/.

Putrawenas, Michael C. 2004. Globalization and Terrorism: Multinational Corporations as Part of the Solution. October 18. Accessed October 28, 2017. http://library.michaelputra.com/2006/04/globalization-and-terrorism-multinationalcorporations-as-part-of-the-solution/.

Sadewo, Bayu. 2017. Ini Kronologis Pemblokiran Telegram yang Sempat Heboh. July 17. Accessed October 29, 2017. https://telset.id/174646/ini-kronologis-pemblokirantelegram-yang-sempat-heboh/.

Tribun Medan. 2017. Diancam Blokir Pemerintah Indonesia, Bos Telegram Pavel Durov Akui Salah. July 17. Accessed October 29, 2017. http://medan.tribunnews.com/2017/07/17/diancam-blokir-pemerintah-indonesia-bostelegram-pavel-durov-akui-salah?page $=1$.

United Nations. 2017. Backgroud. Accessed October 29, 2017. https://www.un.org/counterterrorism/ctitf/en/uncct/background.

Zaenudin, Ahmad. 2017. Mereka yang Memanfaatkan Telegram Selain Teroris. July 19. Accessed October 29, 2017. https://tirto.id/mereka-yang-memanfaatkan-telegramselain-teroris-csXU. 